\title{
Postawa twórcza: zaangażowanie społeczne. Architektura wobec wyzwań nowego stulecia
} Creative Attitude: Public Engagement. of the New Century

\begin{abstract}
Streszczenie
Zasada zrównoważonego rozwoju wraz z intensyfikacją działań dotyczących uwzględniania w procesie projektowania środowiska przyrodniczego spowodowała zmianę sposobu traktowania użytkowników obiektów przez architektów oraz wzrost społecznego zaangażowania tych ostatnich. Wystawy zrealizowanych obiektów oraz decyzje jury Nagrody Pritzker'a podkreśliły znaczenie architektury zaangażowanej społecznie. Analiza postaw twórczych na podstawie tekstów teoretycznych i realizacji stanowi próbę pokazania zarówno historycznej ciągłości, jak i zmian rozwiązań przestrzeni zurbanizowanej i obiektów architektonicznych. Rozważania oparte o wieloletnie obserwacje oraz osobiste doświadczenie dotyczące zagadnień powiązanych z zasadą rozwoju zrównoważonego pozwala na sformułowanie długofalowych wniosków dotyczących sposobów kształtowania środowiska przestrzennego człowieka w zmieniającej się rzeczywistości początku nowego stulecia.
\end{abstract}

\begin{abstract}
The sustainable development rule changed the architects' attitude toward the users of the buildings and an increase in their civic engagement. Exhibitions in New York's MOMA or Frankfurt's Architecture Museum and Pritzker Jury's verdicts underlined the significance of community-engaged architecture and the involvement of an architect in the problems of contemporary society. At the same time, an analysis of theoretical works and everyday architectural practice shows some repetition of the creative design attitude even than the motivation behind it could vary. An analysis of such interwoven relations is an attempt to show the continuity and change in urban and architectural solutions. Such commentary linked to long-standing observations regarding the sustainable development implementation enables us to formulate long-term conclusions for the creation of the human spatial environment in the changing reality of the new century.
\end{abstract}

Słowa kluczowe: architektura zaangażowana społecznie w XXI w., rozwój zrównoważony, postawa twórcza, środowisko człowieka Keywords: Community engaged architecture in the 21. century, sustainable development, design attitude, civic engagement, human environment

\begin{abstract}
Moralnie i społecznie odpowiedzialna jednostka rozpoznaje siebie jako członka większego układu społecznego i w związku z tym uważa problemy społeczne, za przynajmniej czéściowo, za własne; taka jednostka pragnie dostrzegać moralny i społeczny wymiar spraw, by dokonywać i uzasadniać w sposób kompetentny moralne i społecznie opinie, i podejmować działanie, gdy jest to uzasadnione. (Erlich, 2000, s.xxvi)
\end{abstract}

\section{Zasada rozwoju zrównoważonego jako katalizator \\ Zastosowanie zasady rozwoju zrównoważonego w rze- czywistości projektowania architektonicznego i urbani- stycznego przyniosło znaczącą zmianę w postrzeganiu roli architekta w społeczeństwie. Niezbędna zmiana za- chowań społecznych w odniesieniu do środowiska przy-}

A morally and civically responsible individual recognizes himself or herself as a member of a larger social fabric and therefore considers social problems to be at least partly his or her own; such an individual is willing to see the moral and civic dimensions of issues, to make and justify informed moral and civic judgments, and to take action when appropriate. (Erlich, 2000, p.xxvi)

The principle of sustainable development as a catalyst The implementation of the principle of sustainable development in the reality of urban and architectural design has caused a significant change in the perception of the role of the architect in society. The neces- 
rodniczego pozostaje podstawowym priorytetem na początku XXI wieku. Jednocześnie „nasza niezdolność do zrozumienia sposobu działania złożonych i niezależnych całości - interakcji procesów biosfery, użytkowania produkcji energii, działań ekonomicznych, postępu technicznego, zmian społecznych, wydarzeń politycznych, działań zbrojnych - czyni jakiekolwiek prognozowanie (występujące teraz powszechnie) scenariuszy dalszej przyszłości czystą spekulacją." (Smil, 2017, s. 444)

Powszechna popularyzacja elementów tak zwanego myślenia ekologicznego sprawia, że świadomość różnorodnych aspektów kształtowania środowiska zurbanizowanego jest coraz większa. Vaclav Smil w swojej książce na temat historii cywilizacji i użytkowania energii stawia pytania dotyczące długookresowej rentowności życia miejskiego. Jak konstatuje „społeczna spójność i życie rodzinne tak charakterystyczne dla życia wiejskiego z pewnością nie przetrwają w dzisiejszych miastach. Stres życia miejskiego w społecznościach, które dotąd miały charakter wiejski i spoisty uwidacznia się zarówno w narodach bogatych, jak i biednych. Statystyki przestępstw mogą się obniżać w różnych społecznościach, ale duże obszary największych miast świata pozostają uosobieniem przemocy, uzależnienia od narkotyków, bezdomności, porzucania dzieci, prostytucji i okupacji opuszczonych budynków. A jednocześnie, być może bardziej niż kiedyś, wyzwania współczesnej gospodarki wymagają społecznej stabilności i kontynuowania skutecznej współpracy. Miasta zawsze odnawiały się przez migrację z terenów wiejskich - ale co stanie się z już teraz przeważającą cywilizacją miejską kiedy wsie znikną a struktura społeczna miast nadal będzie miała tendencję do dezintegracji?" (Smil, 2017, s.437) Inni takie pytania odnoszą do miejskiej przestrzeni publicznej, przekształcającej się w przestrzeń wirtualną, nie mającą tych samych integrujących społecznie właściwości. (Hoidn, 2016) „Kiedy wchodzimy na plac, ulicę czy do budynku użyteczności publicznej nie zmieniają one swojego kształtu czy tożsamości w odniesieniu do tego kim jesteśmy." (Kern, 2016, s. 18) Ale przestrzeń wirtualna jest sprywatyzowana (eufemistycznie określa się to personalizacją) a wirtualna przestrzeń publiczna nie istnieje. „Wiele z trapiących nas problemów - osłabianie więzi społecznych, wzrost subiektywizacji myślenia, jednostkowość i narcyzm życia kulturalnego - są zarówno przyczyną, jak i konsekwencją cyfrowej rewolucji." (Kern, 2016, s. 18) Innym poważnym problemem jest nierówność i wykluczenie. A nierówności społeczne stanowią jedno z najbardziej zapomnianych zagadnień zrównoważonego rozwoju i wspominają o nich zarówno raport komisji Brundtland jak i encyklika Franciszka „Laudate Si!". Tradycyjnie projektowany obiekt architektoniczny istniał jedynie w wizji architekta i był postrzegany jako skończona artystycznie całość, a nie żyjąca, i zmieniająca się struktura. Ten ostatni aspekt zaczęto uwzględniać razem z uwrażliwieniem na komfort użytkowania budynku przez użytkownika i świadomością, że potrzeby zmieniają się z upływem czasu a projektowanie rozumiane jest jako sary change of social behaviours in reference to the natural environment remains an essential priorirty at the start of the twenty-first century. At the same time, At the same time "our inability to comprehend the behavior of complex and independent wholes - the interactions of biospheric processes, energy production use, economic activities, technical advances, social changes, political developments, armed aggression - make any specific (and now so commonly proffered) scenarios of distant future mere speculation" (Smil, 2017, p. 444).

The general popularisation of the elements of so-called ecological thinking makes people aware of different aspects of the urban environment. Vaclav Smil in his book on the history of energy use and civilisation asks questions about the long-term viability of urban living. As he states: "social cohesion and family nurturing so characteristic of rural life clearly do not prevail in modern cities. The strains of urban living on populations that have been for so long rural and cohesive are manifest in both rich and poor nations. Overall crime rates may have fallen in many nations, but large parts of many of the world's largest cities remain epitomes of violence, drug addiction, homelessness, child abandonment, prostitution, and squad living. And yet, perhaps more than ever, the imperatives of modern economies demand social stability and continuity of effective cooperation. Cities have been always renewed by migration from villages - but what will happen to the already mostly urban civilization once the villages virtually disappear while the social structure of cities continues to disintegrate?" (Smil, 2017, p.437) Others ask questions about the disintegration of public space, as it changes into a virtual one, and as such it does not have the same quality. (Hoidn, 2016) "When we walk into public square, street, or building, they don't change their shape or identity according to who we are." (Kern, 2017 , p. 18) But the virtual reality is privatised (which is euphemistically called "personalisation") while the virtual public sphere is nonexistent. "Many of our troubling problems - the weakening of community, the increasing subjectivity of thought, the personalization and narcissism of cultural life - are both a cause and consequence of the digital revolution." (Kern, 2016, p. 18) Another pressing problem is inequality. Social inequality are some of the most forgotten objectives of sustainability, mentioned both in the Brundtland Report and Pope Francis' Laudate Si! Encyclical.

A traditionally designed work of architecture existed only in the mind of its designer and was seen more like a finished whole, instead of as a living and changeable structure. These aspects of buildings emerged together with the idea of the comfort of the user, the awareness that different needs change with time and the idea of design as a process (see Brand, 
ciągły proces (porównaj Brand, 1995), a nie czynność jednorazowa. A samo pojęcie procesu stanowi istotę idei rozwoju zrównoważonego.

Paradoksalnie te wszystkie zagadnienia w architekturze znalazły swoje rozwiązania zarówno w formie humanistycznej, jaki i stricte technologicznej - cyfrowej. $Z$ jednej strony mamy silne zaangażowanie społeczne, z drugiej coraz większą komputeryzację z użyciem technologii BIM, niezbędnej dla uwzględnienia cyklu życiowego budynku w procesie projektowania. Projektowanie integrujące wszystkie elementy takiego cyklu zakłada przewidywanie wszystkich zmian i starzenia się elementów budynku od poszczególnych materiałów po wykorzystanie energii, itp.. Bez pomocy komputerów zadanie nieomal nierozwiązywalne ze względu na możliwe zmiany i ilości gromadzonych danych wyjściowych. Ale w rzeczywistości praktyki architektonicznej zamiast prowadzić to do bardziej całościowego oglądu powoduje fragmentację elementów projektowania kiedy poszczególne aspekty podlegają coraz większej specjalizacji.

Projektowanie parametryczne, jedna z wiodących idei architektury XXI wieku bazuje na idei autopoiesis architektury. Ta idea techniki komputerowej, rewolucjonizująca podejście do teorii architektury, zaskakująco wywodzi się z nauk biologicznych (tak jak podejście społeczne) definiując życie jako proces samo-reprodukcyjny. Patrik Schumacher, partner w Zaha Hadid Architects, odniósł do architektury teorie systemów społecznych filozofa i socjologa Niklasa Luhmanna. Autopoiesis jest definiowana jako system wzajemnie odnoszących się do siebie struktur komunikacyjnych zdolnych do reprodukcji wszystkich własnych struktur we własnym procesie wewnętrznym. W odniesieniu do struktur społecznych Luhmann używa ścisłej analogii do teorii ewolucji i wskazuje na zróżnicowanie ewolucyjnych mechanizmów różnicowania, selekcji oraz zapamiętywania, które są podstawowe w ewolucji. Schumacher tworzy metodologię mocującą architekturę w systemie społecznym, której podstawy teoretyczne umożliwiają tworzenie wzorców, rozwoju i zasad wewnątrz dyscypliny dając możliwość obserwowania zachodzących zmian. Stworzenie podstaw teoretycznych doprowadziło do sformułowania zasad projektowania parametrycznego, jednego z wiodących trendów projektowych, w którym to wzajemna korelacja i zmienność, dwa podstawowe procesy projektowe opierają się na prawach przyrody. "Zatem wszystko potencjalnie jest siecią i współdziała ze wszystkim. Powoduje to ogólną intensyfikację relacji, która urbanistyce nadaje intensywność wykonania, bogactwo informacyjne oraz spójność poznawczą, razem prowadzące do dobrej czytelności, prostej orientacji i przez to do szybkiego uczestniczenia w zjawiskach społecznych, gdzie umiejętność jednostki do śledzenia wzrastającej równoległości zdarzeń i poruszania się wśród szybko zmieniających się kontaktów stanowi istotną umiejętność kulturową." (Schumacher, 2012, s. 678)

Bardziej ogólna i najbardziej ekologicznie zrównoważona teoria "od kołyski do kołyski" zakłada istnienie sa-
1995), not a finished, complete one-time act. The very notion of the process is the essence of sustainable development.

Paradoxically, all these issues have found there solutions in architecture both in a humanist and strictly technological-digital-form. On the one hand, there is a strong social engagement. On the other, increasing computerisation with the use of BIM technology, necessary to account for the life cycle of buildings in the process of design. Design which integrates all aspects of a building's life cycle is a forecast of all possible developments in function, altering of materials, changes in energy efficiency, etc. This is a task that is almost impossible without the help of computers, due to all the possible unexpected changes and the amount of collected input data. But in the reality of architectural practice, it leads not to a new wholeness but to a fragmentation, as every aspect of the design process undergoes increasingly greater specialisation. Parametric design, one of the main architectural ideas of the twenty-first century, is based on the theory of architecture's autopoiesis. This digital technique, which revolutionises the approach to architectural theory, is surprisingly derived from biological sciences (similarly to the social approach), defining life as a self-reproducing process. Patrik Schumacher, a partner at Zaha Hadid Architects, referenced sociologist Niklas Luhmann's theories of scoial systems to architecture. Autopoiesis is defined as a system of mutually referencing structures within their own internal process. In reference to social structures, Luhmann uses a strict analogy to the theory of evolution and points at the diversity of evolutionary mechanisms of differentiation, selection and memorisation, which are fundamental in evolution. Schumacher creates a methodology which affixes architecture within the social system, and whose theoretical foundations enable the formulation of patterns, development and principles inside the discipline, thereby enabling one to observe change. Creating theoretical foundations led to the formulation of parametric design principles, one of the leading design trends, in which mutual correlation and mutability, two essential design processes, are based on the laws of nature. "Thus everything is potentially made to network and resonate with everything else. This should result in overall intensification of relations that gives the urban field a performative density, informational richness and cognitive coherence that make for good legibility, easy navigation and thus quick, effective participation in a complex social arena where everybody's ability to scan an ever-increasing simultaneity of events and to move through a rapid succession of communicative encounters constitutes the quintessential cultural skill." (Schumacher, 2012, p. 678) 

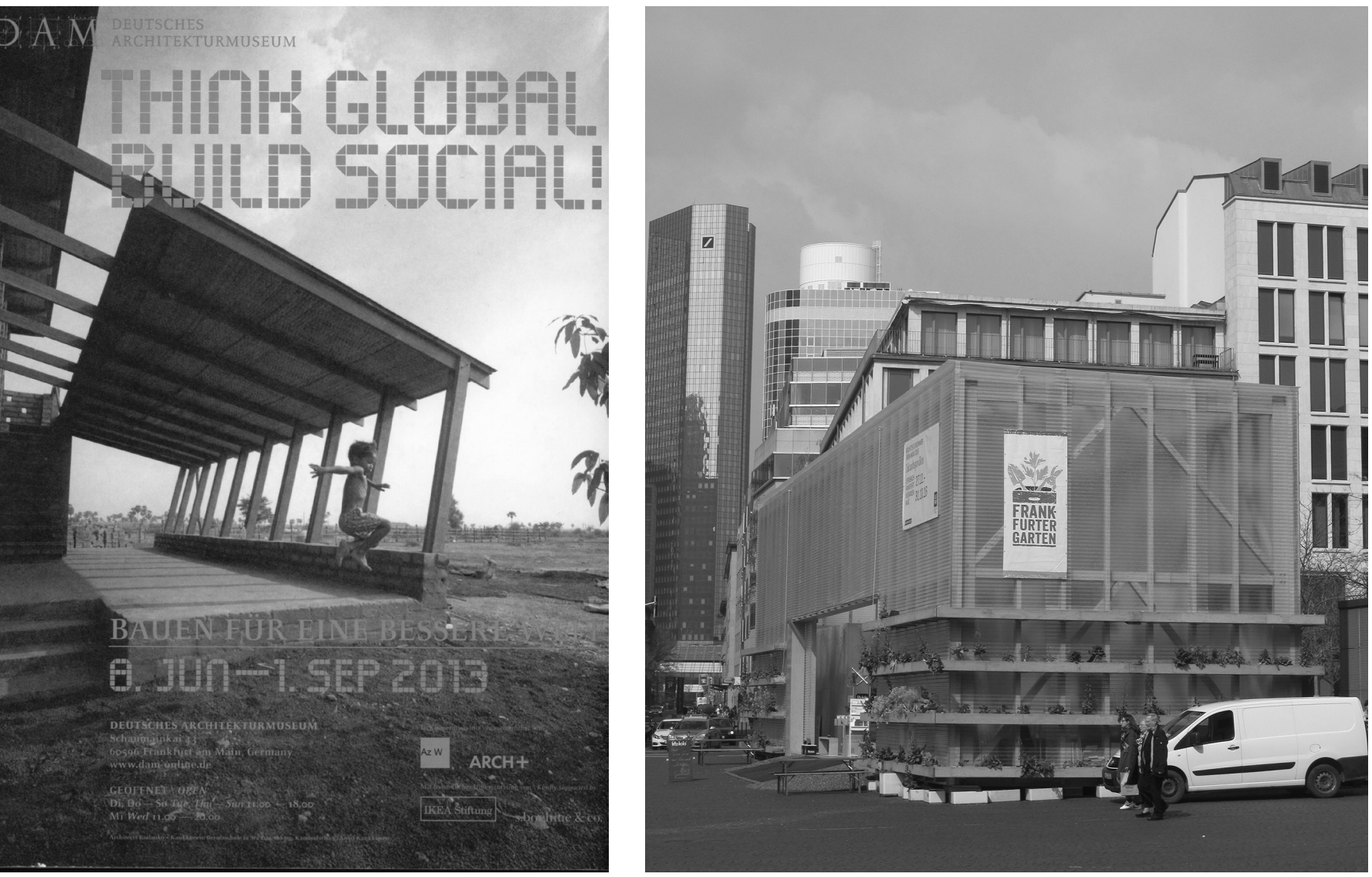

II. 1. Plakat wystawy „Think global. Build local!” zorganizowanej przez DAM, Muzeum Architektury we Frankfurcie n/Menem w Niemczech w 2013 r. Archiwum R. Mikielewicz

II. 1. A poster announcing the „Think global. Build local!"- exhibition organized in DAM, Architecture Museum, Frankfurt am Main, Germany in 2013. Author's archive

II. 2. Frankfurt n/Menem, Niemcy. Tymczasowy pawilon na Placu Schillera, arch. lan Shaw, ASRM 2015. Fot. R. Mikielewicz, 2016 II. 2. Frankfurt am Main, Germany. A temporary pavilion in Schiller Square, arch. lan Shaw, ASRM 2015. Photo: R. Mikielewicz, 2016

mowystarczalności i samoodnowy (podobnie jak idea autopoiesis), ale ma inny punkt wyjścia. Chemik Michael Braungart i architekt William McDonough w roku 2002, w książce 'Cradle to Cradle: Remaking the Way We Make Things' sformułowali zupełnie nowe, również w odniesieniu do zrównoważonego rozwoju, podejście do sposobu tworzenia elementów świata materialnego. Stworzyli koncepcję procesu projektowego opartego o zasadę ciągłej odnowy, tak aby projektowanie stało się środkiem użytkowania zasobów, produkcji i konsumpcji. Zasada opiera się na zrozumieniu potrzeby integrowania budynku z otoczeniem, ale również na całościowych przepływach energii, podobnie jak ekologia definiowana jest w odniesieniu do przyrody. Sformułowanie „kołyska do kołyski" oczywiście odnosi się do powiedzenie "od kołyski aż po grób". Cykl życiowy w środowisku przyrodniczym, gdzie odpad jest początkiem nowego życia, zaprzecza liniowemu życiu materiałów i produktów w społeczeństwie industrialnym. „Od kołyski do kołyski" to założenie, że wszystko co zostanie zużyte zostanie przywrócone do bio- czy technosfery jako tak zwany "techniczny składnik pokarmowy". Recykling obejmuje
The more generally applicable, and the most sustainable theory is "cradle-to-cradle", which assumes the notion of self-dependency and self-renewal, similarly to autopoiesis, although it has a different point of origin. In 2002, Michael Braungart, a chemist, and William McDonough, an architect, in the book entitled Cradle to Cradle: Remaking the Way We Make Things described a completely new approach toward development and the way things should be designed, including in terms of sustainability. The authors created a notion of reconceptualised design based on a cycle of perpetual renewal, in the use of design as means for the change of resource use, production and consumption. The idea is based on the understanding of the necessity to integrate buildings into their urban context, but also on the overall energy flow, as it is defined in ecology, in its basic biological notion. "Cradle-to-cradle" is a rewording of an old saying "from cradle to grave". The life cycle in nature, where waste is changed into new life, contradicts the linear life of materials and products in an industrialised society. In 
tu nie tylko funkcję i formę, ale również skład chemiczny co umożliwia uniknięcie niekorzystnych skutków ubocznych. McDonough and Braungart zakładają, że rozwiązania architektoniczne współczesnych budynków reprezentują sposób dawny sposób myślenia poprzez swoje uniwersalistyczne rozwiązania. Jako przeciwieństwo budynki kształtowane zgodnie z zasadą "od kołyski do kołyski" powinny mieć cechy drzewa, powiązanego z naturalnymi przepływami energii (wiatr, energia słoneczna, woda) tak by uwzględniać zmiany pór roku i stanowić część środowiska naturalnego. Jako swoista architektura ciągłych początków, obiekt zbudowany powinien dawać możliwość ciągłego przeprojektowywania swojej struktury technicznej i społecznej. (patrz McDonough, Braungart, 2009; Cairns, Jacobs, 2014)

Te uzupełniające się, czy może wzajemnie sprzeczne poglądy stanowią tło dla architektury społecznie zaangażowanej na początku nowego stulecia.

\section{Zaangażowanie społeczne jako postawa twórcza}

W roku 1969, Giancarlo De Carlo, w jednym z podstawowych tekstów dotyczących partycypacji społecznej "Il pubblico dell'architettura / Architecture's Public" (De Carlo, 2013) wyraził swój sprzeciw przeciwko porzuceniu społecznych ideałów modernizmu. Współcześni architekci dyskutują na temat roli architekta w społeczeństwie i nawet wyraźniej łączą ją z ideą aktywnego współdziałania.

“Istnieje wiele możliwości działania dla jednostki, by rozwinąć własną twórczość I być aktywnym jako obywatel-architekt. Przyjmij za zasadę, że problem należy zidentyfikować I próbować go rozwiązać. Możesz zająć się problemem znanym, albo wyeksponować problem przeoczony. Zrób to sam lub stwórz zespół. Możesz nie znać wszystkich odpowiedzi, i to jest w porządku; bądź tylko przygotowany do zrobienia wszystkiego czego wymaga rozwiązanie problemu. Jeśli twoje propozycje znajdą uznanie, może zaskoczyć cię ile zainteresowania i wsparcia możesz wygenerować swoim wysiłkiem." (Peterson, 2008, s. 103)

“Odwiedziny w domu sąsiada mogą zbudować osobiste relacje i dać wartościowe informacje na temat zachowań społeczności lokalnej. Podzielenie się posiłkiem z klientem może projektanta nauczyć więcej na temat lokalnych uwarunkowań niż jakikolwiek rozbudowany kwestionariusz." (Hendler-Voss, s.127)

Tego typu sformułowania znajdują potwierdzenie w pracach takich architektów jak Balkrishna Doshi i Alejandro Aravena. Obaj architekci, choć z różnych pokoleń, postawili w swojej pracy na zaangażowanie społeczne. Jak mówi Doshi „zrozumiałem, że architektura jest tłem, aktywuje życie jeśli z nim współgra. Wzmacnia zdarzenia w ich sensorycznym wymiarze takim jak światło, przestrzeń, forma, struktura, faktura, kolor, rytm oraz wzmacnia nasze umiejętności i jest katalizatorem zdarzeń i rytuałów." (Doshi, 2018)

Aravena rozwiązuje swoje projekty domów Elemental koncentrując się (w jego własnych słowach) na tym 'cradle-to-cradle' the materials and objects with spent utility could be cycled back into the techno- or biosphere-as so-called "technical nutrients". They are recycled because of their function and form, but also because of their chemical composition, which enables them to avoid the dangers of unknown side-effects. McDonough and Braungart assume that universal architectural solutions, as represented in contemporary buildings, are locked into the cradle-to-grave design as they represent a one-size-fits-all design. Otherwise, the buildings formed using a "cradle-to-cradle" design approach should have tree-like features connecting with the flow of natural energies such as wind, sun or water to change with the seasons, and remain a part of the natural environment. As a kind of architecture of perpetual beginnings, the built object should be able to be redesign in its material and social structure. (see McDonough, Braungart, 2009; Cairns, Jacobs, 2014) Such complementing or perhaps mutually contradicting approaches build the backdrop for communityengaged architecture at the start of the new century.

\section{Civic engagement as an attitude}

In 1969, Giancarlo De Carlo, in one of the key texts on public participation // pubblico dell'architettura (Architecture's Public) (De Carlo, 2013) expressed his anger about the betrayal of the social ideals of Modernism in architecture. Contemporary architects discuss the role of the architect in modern society and even more strongly connect with the idea of active participation.

"There are countless things you can do as an individual to expand your work and be more active as a citizen-architect. Take it upon yourself to identify a problem in the public realm and pursue a solution. You can choose a known problem, or you might expose one that has been overlooked. Do it alone or build a team. You may not have all the answers, and this is fine; just be prepared to do what it takes to move the idea or project forward. If your proposal resonates with people, you may be surprised by how much interest and support your efforts generate." (Peterson, 2008, p. 103)

"Visiting a home of a neighborhood resident can build personal relationships and provide valuable insight into the culture of a community. Sharing a meal with a client can teach designers more about local dynamics than a boilerplate questionnaire can." (Hendler-Voss, p.127)

Such insights resonate with the work of such architects as Balkrishna Doshi and Alejandro Aravena. Architects from different generations, both concerned with civic engagement in their work. Doshi states: "I also recognized that architecture is a backdrop, it proactivates life when in tune. It heightens all the events 
co zagwarantuje dobro wspólne w przyszłości. (Aravena, lacobelli, 2016) Idea rozwijających się domów ma u podstaw chęć poprawy ludzkiej egzystencji. Architekt angażuje się również w proces finansowania i całościowego procesu budowy jednostek mieszkaniowych. Takie podejście jest zgodne z definicją projektowania przyjętą przez SEED ((Social, Economic, and Environmental Design Network) rozumiejącą projektowanie jako interdyscyplinarny i zespołowy proces, którego pożądanym efektem jest poprawa warunków egzystencji. (Wilson, 2008 , s. 31) Najważniejszą cechą takiego procesu projektowego jest zespołowość współpracy i partycypacja w tym procesie późniejszych użytkowników.

Kiedy kolegium sędziów Nagrody Pritzker'a przyznawało ją w 2106 roku Aravenie w uzasadnieniu napisano, że nadaje on „(...) zawodowi architekta nowy wymiar, niezbędny dla dzisiejszych i przyszłych wyzwań w dziedzinie architektury. (...) To innowacyjne podejście poszerza tradycyjny zakres działań architekta i przekształca przedstawicieli zawodu w uniwersalnego specjalistę zdolnego odnaleźć naprawdę wspólne rozwiązania dla środowiska zurbanizowanego", a tym samym Aravena "uosabia powrót bardziej społecznie zaangażowanego architekta (...), rozumiejąc dogłębnie zarówno architekturę, jak i społeczeństwo" oraz "(...) jest czołowym przedstawicielem pokolenia architektów mających całościowe podejście do środowiska zurbanizowanego prezentując zdolność do łączenia odpowiedzialności społecznej, wymagań ekonomicznych, projektowania środowiska ludzkiego, oraz miast." (Pritzker Architecture Prize, 2016) W uzasadnieniu werdyktu nagrody Balkrishny Doshi'ego z 2018 roku czytamy, że "Doshi jest wyjątkowo świadomy kontekstu, w jakim sytuowane są jego budynki. Jego rozwiązania projektowe uwzględniają społeczne, środowiskowe i ekonomiczne uwarunkowania co powoduje, że jego architektura jest całościowo zrównoważona." (Pritzker Architecture Prize, 2018)

Giancarlo De Carlo dalekowzroczne uwagi o roli architektów, czy architektury w społeczeństwie wynikają z konstatacji, że „świat nie istnieje bez architektury. (...) Ponadto, podstawowym powodem istnienia istot ludzkich na tym etapie ewolucji, jest dokonywanie świadomego przeobrażania otaczającego środowiska. (...) Kiedy ludzka aktywność wzrasta, stając się bardziej zróżnicowana i wszechobecna, decyzje gdzie powinna się koncentrować dotyczą sfery ekonomicznej, biurokratycznej i technologicznej. Rolą architektury jest zatem zaangażowanie w procesy zamrażania lub odmrażania elementów tego paradoksu, zgodnie ze stanowiskiem jakie zostanie przyjęte - po stronie struktur władzy, albo po stronie tych, którzy są zniewoleni lub wykluczeni." (De Carlo, 2013, s. 92)

To co do dziś pozostało aktualne to świadomość, że architekci "koncentrując się na problemie "jak", oddają pole strukturom władzy. Zaniedbując problemy "dlaczego", gubią z pola widzenia najważniejszy powód swojego kulturowego społecznego umocowania." (De Carlo, 2013, s.90) to their ultimate sensations such as light, space, form, structure, texture, color, rhythm and heightens our skills and catalyzes events and rituals." (Doshi, 2018). Aravena designs his Elemental projects focus (in his own words) on what will guarantee the common good in the future. (Aravena, lacobelli, 2016) The idea of incremental housing entertains an idea of a possibility for the improvement of human existence. The architect is also involved in the process of financing and the overall development of housing projects. Such an approach is consistent with the SEED (Social, Economic, and Environmental Design Network) definition of design as a transdisciplinary and collaborative process where the desired outcome should improve human existence. (Wilson, 2008, p.31) Here, collectivity in design and user participation are the most important part of the design process.

When the Pritzker Prize Jury awarded Alejandro Aravena the Prize in 2016, in the citation, the members wrote that he "(...) gives the profession of architect a new dimension, which is necessary to respond to present demands and meet future challenges of the field. (...) This inventive approach enlarges the traditional scope of the architect and transforms the professional into a universal figure with the aim of finding a truly collective solution for the built environment" so he "(...) epitomizes the revival of a more socially engaged architect (...) has a deep understanding of both architecture and civil society" and "(...) is leading a new generation of architects that has a holistic understanding of the built environment and has clearly demonstrated the ability to connect social responsibility, economic demands, design of human habitat and the city." (Pritzker Architecture Prize, 2016) In the citation for Balkrishna Doshi in 2018, the Jury stressed, that "Doshi is acutely aware of the context in which his buildings are located. His solutions take into account the social, environmental and economic dimensions, and therefore his architecture is totally engaged with sustainability." (Pritzker Architecture Prize, 2018).

Giancarlo De Carlo's far-sighted remarks on the role of architects or architecture in society emerge from the statement that "the world cannot do without architecture. (...) Besides, the main raison $d^{\prime}$ tre of human beings in this stage of their evolution is the destiny of making conscious transformations of their environment. (...) While human activities multiply, becoming diversified and omnipresent, decisions about where they should take place are increasingly concentrated in the spheres of economic, bureaucratic and technological power. The role of the architecture could be to contribute to the freezing or thawing out of this paradox, according to the stand it chooses to take - on the side of the power structure, or on the side of those over- 


\section{Zmiana jako konieczność}

W roku 2015, w centrum rozległej, amorficznej przestrzeni frankfurckiego Placu Schiller'a stanął prostopadłościenny pawilon (arch. lan Shaw). Prosta forma zaprojektowana z użyciem ogólnodostępnych w marketach budowlanych płyt poliuretanowych i drewnianych udekorowano doniczkami z warzywami (użytymi jako obciążenie konstrukcji). Estetycznie pawilon wyróżniał się z otoczenia okolicznych, połyskujących, wieżowców i kamienic przypominając porzuconą po przeprowadzce paczkę. Tymczasowy obiekt, który postawiono z okazji festiwalu architektury ASRM (Architektursommer Rhein-Main) 2015 specjalnie jako miejsce spotkań i dyskusji dotyczących rozwiązań urbanistycznych dla miasta (Frankfurt Pavilion, 2015), już samą formą "manifestującą poprzez zmaterializowany system samo-prezentacji" (De Carlo, 2013, s.90) nawiązywał on do zmiany podejścia $w$ architekturze odnosząc się nie tylko do problemów otaczającej przestrzeni ale zagadnień globalnych jak klimat, nierówności różnego rodzaju, wykorzystanie czasu, itp.

Wystawy takie jak frankfurckiego Muzeum Architektury "Think global, build social!" (2013), nowojorskiej MOMA "Small Scale, Big Change: New Architectures of Social Engagement" (2010) (MOMA 2010) czy berlińska DEMO-POLIS - The Right to Public Space (Akademie der Künste, 2016) dotknęły istotnych problemów współczesnego świata udowadniając istnienie potrzeby zaangażowania architektów $w$ ich rozwiązywanie. Zaangażowana socjalnie architektura może stanowić jedyna kreatywną niszę projektowania architektonicznego w obliczu coraz bardziej dominujących wymagań technologicznych i różnorakich sposobów certyfikowania, które coraz bardziej określają formułę współczesnego procesu projektowego. Dzięki takiej architekturze zyskują głos grupy społeczne wykluczone socjalnie - poprzez partycypację oraz poprzez formę architektoniczną i urbanistyczna zabudowy. Takie projekty uwzględniają również możliwość późniejszych zmian. Architekt jest niejako zobowiązany do użycia lokalnych tradycji i zasad współżycia społecznego i integrowania lokalnej społeczności. Inne podejście dotyczy również sposobu wykorzystywania zasobów i gospodarowania odpadami. Ale najważniejszym zagadnieniem jest zasada sprawiedliwości społecznej i uwzględnianie różnorodności tożsamości oraz kultur, oraz wynikająca z tego idea tworzenia środowiska zurbanizowanego, gdzie każdy może być członkiem społeczności funkcjonującej na zdrowych zasadach społecznych, ekonomicznych i środowiskowych. (Wilson, 2008, s.30)

W projektach opartych na takich zasadach, można odnaleźć nie tylko kreację przestrzenną, ale dążenie do budowania wspólnoty. Istotą projektu jest nie to materialne ale to co społeczne, nawet jak wyraża się w użyciu tradycyjnych technik budowania z gliny. I stanowi różnicę w stosowaniu zasady rozwoju zrównoważonego - nacisk kładziony jest aspekt ludzki a sprawność whelmed and excluded by it." (De Carlo, 2013, p.92)

That which has remained true today is the knowledge that architects "concentrating on the problems of 'how', they played into the hands of the power structure. In neglecting the problems of 'why', they lost track of the most important reasons for their cultural commitment." (De Carlo, 2013, p.90)

\section{Change as a necessity}

In 2015, in the middle of the enormous, rather amorphous space of Frankfurt am Main's Schiller Square, a pavilion was built (arch. lan Shaw). The simple form, designed with the use of polyurethane and wood panels readily available in construction stores, was decorated with vegetable plant pots (used to provide ballast to the structre). Aesthetically, the pavilion stood out from its surroundings which were composed of glimmering towers and townhouses, resembling a package misplaced during moving. The temporary building, which was built on the occasion of the ASRM 2015 architecture festival (Architektursommer RheinMain) specifically as a meeting space for discussions on urban solutions for the city (Frankfurt Pavilion, 2015), referenced the change in approach to architecture already through its form, "communicating via materialized systems of self-representation" (De Cardlo, 2013 , p. 90), referring not only to the problems of the surrounding space, but also global issues such as climate, all sorts of inequality, time consumption, etc. Exhibitions like Frankfurt's DAM "Think global, build social!" (2013), New York's MOMA „Small Scale, Big Change: New Architectures of Social Engagement" (2010) (MOMA, 2010) or Berlin's Akademie der Künste DEMO-POLIS - The Right to Public Space (2016) also addressed the pressing issues of the contemporary world showing a clear statement about the necessity of architects' participation in the solutions of the problems. Socially-engaged architecture can consitute the sole creative niche of architectural design in the face of increasingly prevalent technological requirements and all forms of certification, which define the formula of the contemporary design process to a progressively greater degree. Disadvantaged social groups should get a voice this way-in the participation process and through architectural or urban form. Such projects also account for possible future changes. An architect is obligated to use local traditions and principels of social coexistence and to integrate the community around the project. Another paradigm builds resource and waste management. But the most important issue is social justice and inclusion of multicultural values and identities. The most binding rule enables every individual to live in the community with a healthy social, economic and environmental system. (Wilson, 2008, p.30) 

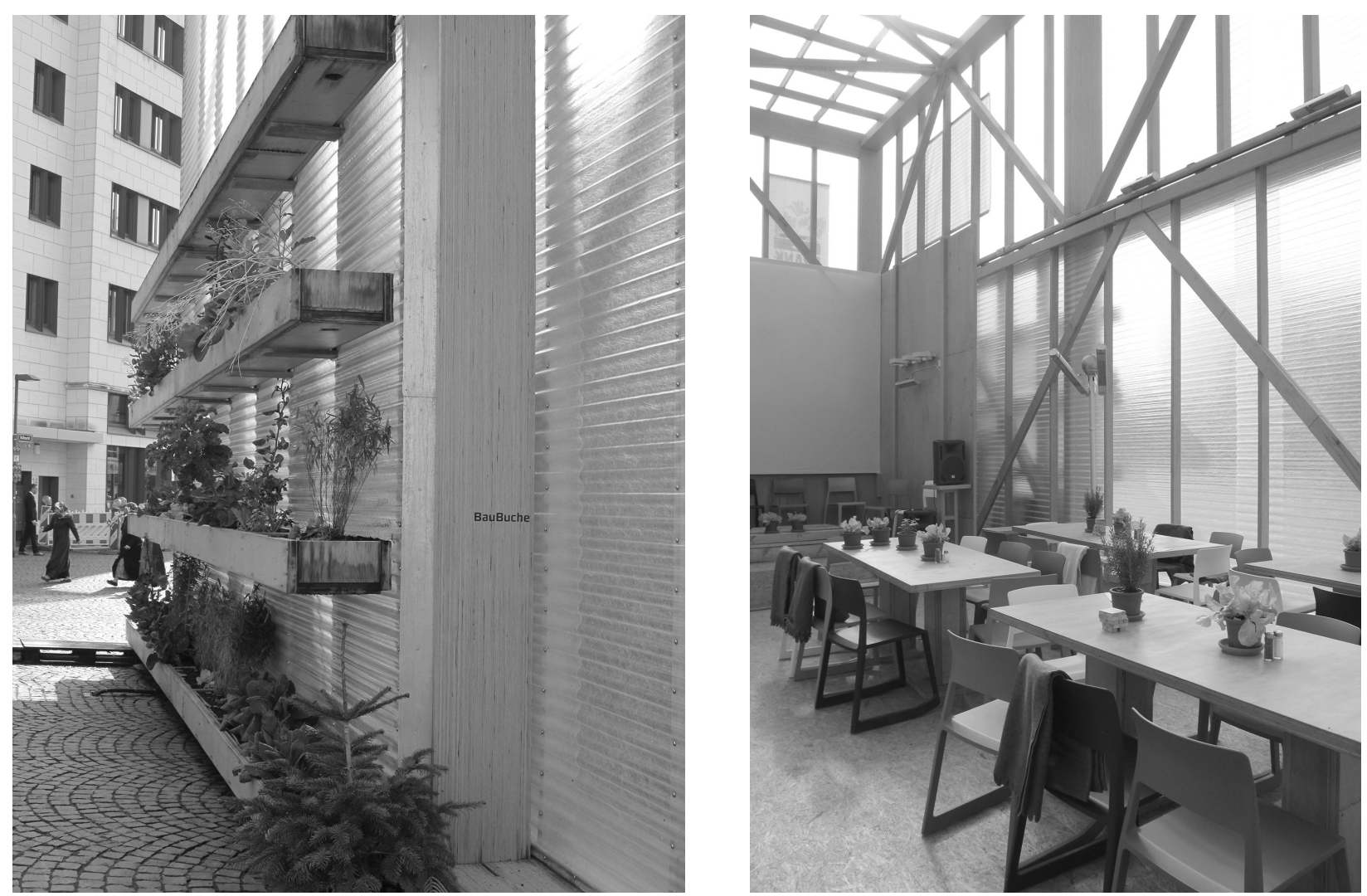

II. 3. Frankfurt n/Menem, Niemcy. Ściana pawilonu na Placu Schillera z drewna bukowego $i$ poliwęglanu - doniczki z warzywami oprócz aspektu estetycznego miały funkcję konstrukcyjną ze względu na brak posadowienia obiektu. Fot. R. Mikielewicz, 2016

II. 3. Frankfurt am Main, Germany. The Schiller Square Pavilion wall from commercial wood beams and polymer sheeting loaded with, stating environmental aesthetic, vegetable flowerpots for construction reasons. Photo: R. Mikielewicz, 2016

II. 4. Frankfurt n/Menem, Niemcy. Wnętrze tymczasowego pawilonu na Placu Schillera, służące jako miejsce spotkań $i$ dyskusji ASRM 2015. Fot. R. Mikielewicz, 2016

II. 4. Frankfurt am Main, Germany. The interior of the temporary Schiller Square Pavilion, the meeting and discussion place of ASRM 2015. Photo: R. Mikielewicz, 2016

energetyczna nie jest mierzona grubością warstwy izolacji termicznej. Projekty prezentowane we Frankfurcie i Nowym Jorku to zarówno budynki użyteczności publicznej Np. Peter'a Rich'a południowoafrykańskie centrum kulturalne czy marokańskie lub bangladeskie szkoły Anny Heringer), jak i komunalne zespoły mieszkaniowe (np. domy Elemental). Architektura o silnym w swej prostocie wyrazie, o klarownej i wyrafinowanej elegancji.

Nie jest pewne czy nowa społecznie zaangażowana architektura utożsamia to co powszechne, ale na pewno dokumentuje potrzebę zmiany kształtu środowiska zurbanizowanego wyrażając zmianę systemu wartości w spolaryzowanym społeczeństwie. Amerykański architekt N. J. Habraken twierdzi, że nowe można jedynie wtedy uznać za coś trwałego dokumentującego nasze dokonania, gdy wchodzi do powszechnego użycia i zyskuje status zwyczajności. (Habraken, 2000, ss.11, 327) Należy zatem mieć nadzieję, że jakościowa zmiana warunków życia użytkowników będąca wynikiem społecznie zaangażowanej architektury zyska status nowego standardu.
In designs based on such principles, we can find not only spatial design, but the desire to build a community. The essence of the design is not so much material as it is social, even if it manifests itself in the use of old traditional techniques of clay brick-laying. And the contrast in the use of the principle of sustainable development-the emphasis lies completely on the human aspect and energy efficiency is not defined as insulation thickness. Projects presented in Frankfurt and New York embraced public buildings (as Peter Rich's South African cultural centre or Anna Heringer's schools in Marocco or Bangladesh) and communal housing projects, such as the previously mentioned Elemental houses. It is an architecture with strong simplified expression, but with clarity and sophisticated elegance. It is not certain if the new socially engaged architecture embodies that whichh is common, but it certainly documents the need for change in the built environment expressing the shift in a polarised society. The American architect N. J. Habraken advocates that the new can only be acknowledged as something that lasts and documents our achievements when it enters com- 
Po dokładnie 50 latach, od wykładu De Carlo, po 20 latach nowego stulecia można za włoskim architektem powtórzyć, że “(...) architektura stała się zbyt ważna by zostawić ją tylko architektom". (De Carlo, 2013, s.92)

\section{BIBLIOGRAFIA}

[1] Aravena, A., lacobelli A., Elemental: Incremental Housing and Participatory Design Manual, Hatje Cantz, Ostfildern 2016

[2] Brand S., How Buildings Learn. What Happens After They're Built, Penguin, London 1995

[3] De Carlo G., Architecture's Public. The Revolt and the Frustration of the School of Architecture, (1970), s. 88-96 w: Arch+ Journal for Architecture and Urbanism. 221/212. Think Global, Build Social!, Year 46, Vol.46, 2013

[4] Doshi B., Ceremony Acceptance Speech, 2018, https://www. pritzkerprize.com/sites/default/files/inline-files/2018 BalkrishnaDoshi_CeremonySpeech.pdf (dostęp: 19.02.2020)

[5] Ehrlich T. ed., Civic Responsibility and Higher Education, Oryx Press, 2000. Introduction, p. xxvi. Żródło: https://archive.nytimes. $\mathrm{com} / \mathrm{www}$.nytimes.com/ref/college/collegespecial2/coll_aascu_ defi.html. (dostęp:18.02.2020)

[6] Frankfurt Pavilion, artykuł czasopisma Baunetz.de, 2015, https:// www.baunetz.de/meldungen/Meldungen-ASRM eroeffnet PavilIon in Frankfurt 4634611.html (dostęp: 18.02.2020)

[7] Habraken N.J., The Structure of the Ordinary. Form and Control in the Built Environment, The MIT Press, Cambridge, Massachusetts, London, England 2000

[8] Hendler-Voss A., Hendler-Voss S., Designing with an Asset-Based Approach, s. 124 - 139 w: Expanding Architecture. Design as Activism, B. Bell, K. Wakeford (red.), Metropolis Books, New York 2008

[9] Hoidn B., ed., DEMO:POLIS: The Right to Public Space, Park Books, Zurich, 2016

[10] Kern A. On Virtual and Real Public Space, s. 16 - 18, w: DEMO:POLIS: The Right to Public Space, ed. B. Hoidn, Park Books, Zurich, 2016

[11] McDonough W., Braungart M., Cradle to Cradle. Remaking the Way We Make Things, Vintage Books, London 2009

[12] MOMA, Small Scale, Big Change: New Architectures of Social Engagement, 2010, exhibition information, Museum of Modern Art, New York, http://www.moma.org/interactives/exibitions/2010/ smallscalebigchange/ (dostęp: 15.06.2014)

[13] Pritzker Architecture Prize, 2016, Jury Citation for Alejandro Aravena, www.pritzkerprize.com/2016/jury-citation (dostęp: 24.04.2017)

[14] Pritzker Architecture Prize, 2018, Jury Citation for Balkrishna Doshi, https://www.pritzkerprize.com/laureates/balkrishna-doshi. (dostęp: 19.02.2020)

[15] Schumacher P., The Autopoiesis of Architecture. A New Agenda for Architecture, Vol. II, John Wiley \& Sons Ltd, Chichester 2012 [16] Smil V., Energy and Civilization. A History, The MIT Press, Cambridge, Massachusetts 2017

[17] Wilson B.B., The Architectural Bat-Signal: Exploring the Relationship between Justice and Design, s. 28-33 w: Expanding Architecture. Design as Activism, B. Bell, K. Wakeford (red.), Metropolis Books, New York 2008 mon use and gains the status of being ordinary (Habraken, 2000 , pp.11, 327). Therefore, we should hope that the quality change in the ordinary life of the users which provides the community-engaged architecture will build the new ordinary. After exactly 50 years, 20 years into the new century we certainly can join De Carlo in his statement that "(...) architecture has become too important to be left to architects". (De Carlo, 2013, p. 92)

\section{REFERENCES}

[1] Aravena, A., lacobelli A., Elemental: Incremental Housing and Participatory Design Manual, Hatje Cantz, Ostfildern 2016

[2] Brand S., How Buildings Learn. What Happens After They're Built, Penguin, London 1995

[3] De Carlo G., Architecture's Public. The Revolt and the Frustration of the School of Architecture, (1970), s. 88-96 w: Arch + Journal for Architecture and Urbanism. 221/212. Think Global, Build Social!, Year 46, Vol.46, 2013 [4] Doshi B., Ceremony Acceptance Speech, https://www.pritzkerprize. com/sites/default/files/inline-files/2018_BalkrishnaDoshi_CeremonySpeech.pdf (Accessed: 19.02.2020)

[5] Ehrlich T. ed., Civic Responsibility and Higher Education, Oryx Press, 2000. Introduction, p. xxvi. From: https://archive.nytimes.com/www. nytimes.com/ref/college/collegespecial2/coll_aascu_defi.html. (Accessed:18.02.2020)

[6] Frankfurt Pavilion, an article in the journal Baunetz.de, 2015, https:// www.baunetz.de/meldungen/Meldungen-ASRM_eroeffnet_Pavillon_in Frankfurt 4634611.html (Accessed: 18.02.2020)

[7] Habraken N.J., The Structure of the Ordinary. Form and Control in the Built Environment, The MIT Press, Cambridge, Massachusetts, London, England 2000

[8] Hendler-Voss A., Hendler-Voss S., Designing with an Asset-Based Approach, p. 124 - 139 w: Expanding Architecture. Design as Activism, B. Bell, K. Wakeford (red.) Metropolis Books, New York 2008

[9] Hoidn B., ed., DEMO:POLIS: The Right to Public Space, Park Books, Zurich, 2016.

[10] Kern A. On Virtual and Real Public Space, p. 16 - 18, w: DEMO:POLIS: The Right to Public Space, ed. B. Hoidn, Park Books, Zurich, 2016

[11] McDonough W., Braungart M., Cradle to Cradle. Remaking the Way We Make Things, Vintage Books, London 2009

[12] MOMA, Small Scale, Big Change: New Architectures of Social Engagement, 2010, exhibition information, Museum of Modern Art, New York http://www.moma.org/interactives/exibitions/2010/smallscalebigchange/ (Accessed: 15.06.2014)

[13] Pritzker Architecture Prize, 2016, Jury Citation for Alejandro Aravena www.pritzkerprize.com/2016/jury-citation (Accessed: 24.04.2017)

[14] Pritzker Architecture Prize, 2018, Jury Citation for Balkrishna Doshi, https://www.pritzkerprize.com/laureates/balkrishna-doshi. (Accessed: 19.02.2020)

[15] Schumacher P., The Autopoiesis of Architecture. A New Agenda for Architecture, Vol. II, John Wiley \& Sons Ltd, Chichester 2012

[16] Smil V., Energy and Civilization. A History, The MIT Press, Cambridge, Massachusetts 2017

[17] Wilson B.B., The Architectural Bat-Signal: Exploring the Relationship between Justice and Design, p. 28-33 w: Expanding Architecture. Design as Activism, B. Bell, K. Wakeford (red.), Metropolis Books, New York 2008 